\title{
Pelaksanaan Program Karang Taruna dalam Pembinaan Remaja di Kenagarian Sitiung
}

\author{
Mira Anggita Sari, Muhammad Prima Ersya \\ Program Studi Pendidikan Pancasila dan Kewarganegaraan \\ Universitas Negeri Padang \\ E-mail: anggitasarimira@gmail.com
}

\section{ABSTRAK}

Tujuan dari penelitian ini adalah untuk mendeskripsikan pelaksanaan program karang taruna dalam membina remajanya, hambatan pelaksanaan program karang taruna serta langkah efektif untuk menaggulangi hambatan tersebut. Metode penelitian yang dipakai pada penelitian ini adalah metode deskriptif kualitatif. Dengan teknik pengumpulan data yaitu melalui observasi dan wawancara. Lokasi penelitian yaitu di Kenagarian Sitiung yang dilaksanakan pada bulan Mei s/d Juni 2019. Hasil penelitian menunjukan bahwa pelaksanaan program karang taruna di Kenagarian Sitiung dalam membina remajanya yaitu dengan mengadakan kegiatan yang positif yang dapat membentuk karakter remaja menuju kearah yang lebih baik, penelitian ini perlu dilakukan untuk melihat bagaimana pembinaan tersebut dalam membentuk suatu organisasi yang dapat menjadi wadah pembinaan bagi remaja. Kesimpulan dari penelitian yang dilakukan maka pelaksanaan program karang taruna dalam pembinaan remaja di Kenagarian Sitiung di setiap Jorong memiliki program pembinaan remaja dan melaksanakan program yang dibuatnya, seperti pelaksanaan kegiatan kesejahteraan sosial, agama, keterampilan dan olahraga. Namun ada beberapa program yang belum berjalan untuk membina remajanya.

Kata Kunci: pelaksanaan program, karang taruna, pembinaan

\section{ABSTRACT}

The purpose of this study is to describe the implementation of the youth program in fostering adolescents, the obstacles in the implementation of the youth program and effective steps to overcome these obstacles. The research method used in this research is descriptive qualitative method. With data collection techniques, namely through observation and interviews. The research location is in Kenagarian Sitiung which was carried out in May to June 2019. The results showed that the implementation of the youth program in Kenagarian Sitiung in fostering adolescents is by holding positive activities that can shape the character of adolescents towards a better direction, this research needs to be done to see how the coaching in forming an organization that can be a forum for coaching for adolescents. The conclusion of the research conducted is the implementation of youth programs in youth coaching in Kenagarian Sitiung in each Jorong has a youth coaching program and implement programs that are made, such as the implementation of social welfare, religious activities, skills and sports. But there are some programs that are not yet running to foster adolescence 
Keywords : program implementation, youth organization, youth developmen

This work is licensed under the Creative Commons Attribution-ShareAlike 4.0 International License. (2019 by author and Universitas Negeri Padang.

\section{PENDAHULUAN}

Remaja merupakan suatu generasi yang dibebani bermacammacam harapan untuk generasi lainnya, karena remaja merupakan generasi penerus yang akan melanjutkan perjuangan generasi sebelumnya, agar mereka menjadi individu yang berguna. Menurut Sarwono (2007) remaja merupakan suatu masa individu berkembang yang menunjukkan tanda-tanda yang mengalami perkembangan psikologis dan pola berfikir dan akan memilih jalannya sendiri karena ia tahu saatsaat berbahaya dan ia dapat menentukan harus kembali berkonsultasi dengan orang tua atau orang-orang dewasa lainnya yang lebih tau dari dirinya sendiri. Namun, realitanya saat ini banyak pihak yang meragukan hal tersebut. Karena, kenakalan remaja yang melanda akan meruntuhkan moral dan akhlak remaja masa kini. Menurut Soekanto (2013: 393) secara psikologis usia remaja merupakan umur yang dianggap "gawat" karena masa remaja merupakan masa mencari identitasnya. Hal ini menggambarkan betapa seriusnya fenomena ini dan diperlukan langkah-langkah yang tegas untuk membendung permasalahan pada remaja saat ini. Untuk dapat memecahkan permasalahan tersebut maka diperlukan suatu wadah untuk membina remaja serta mengarahkan remaja tersebut ke arah yang lebih baik. Pelaksanaan pembinaan tersebut adalah tugas pokok dan kewajiban dari pelaksana pembinaan organisasi tersebut, baik itu dari pusat maupun dari daerah sesuai bidangnya. Penelitian perlu dilakukan dengan pertimbangan bahwa remaja saat ini sangat memperhatikan oleh sebab itu diperlukan suatu program yang dapat membina remaja dalam berkehidupan di lingkungan masyarakat. Salah satu organisasi yang dijadikan wadah untuk pembinaan remaja yaitu organisasi karang taruna. Hal ini sama yang di sampaikan oleh penelitian yang dilakukan oleh Mochamad Ridwan Arif (2014) diperlukan suatu wadah untuk membina dan mengarahkan generasi muda tersebut yaitu dengan membentuk suatu organisasi yang nantinya akan menjadi wadah pernbinaan generasi muda tersebut khususnya di pedesaan. Sesuai dengan Undang-Undang Republik Indonesia No 4 Tahun 2009 pasal 22 ayat 1 tentang Kepemudaan menyatakan bahwa: Penyadaran kepemudaan berupa gerakan pemuda dalam aspek ideologi, politik, hukum, ekonomi, sosial budaya, pertahanan dan keamanan dalam memahami dan menyikapi perubahan lingkungan strategis, baik domestik maupun global serta mencegah dan menangani resiko.

Sesuai dengan Peraturan Menteri Sosial Republik Indonesia No 77 Tahun 2010 Pasal 1 Ayat 1 tentang Pedoman Dasar Karang Taruna adalah: Karang taruna adalah organisasi sosial kemasyarakatan sebagai wadah dan sarana pengembangan setiap anggota masyarakat yang tumbuh dan 
berkembang atas dasar kesadaran dan tanggung jawab sosial. Adapun visi karang taruna yaitu sebagai wadah pembinaan dan pengembangan kreativitas generasi muda yang berkelanjutan untuk menjalin persaudaraan dan rasa kebersamaan menjadi mitra organisasi lembaga, baik kepemudaan ataupun pemerintah dalam pengembangan kreativitas.

Namun, pada kenyataannya di Kenagarian Sitiung masih ada remaja yang tidak peduli atau tidak tanggap terhadap kegiatan kepemudaan karena belum berfungsinya karang taruna. Hal ini terjadi karena kurangnya pengawasan dan pembinaan dari program karang taruna. Tugas karang taruna sebagai wadah pembinaan remaja tidak berjalan sesuai dengan yang diharapkan. Banyak target yang tidak berjalan seperti dihapusnya kegiatan pengajian pemuda di jorong Piruko Utara. Hal ini sesuai dengan yang disempaikan oleh pendapat salah satu pemuda Jorong Lawai Roli (18 maret 2018 ) menyatakan bahwa: “Karang taruna di Jorong tersebut sudah mulai tidak berperan aktif dalam pembinaan generasi muda. Pemuda tidak peduli atau tidak mau mengasah atau menyalurkan potensi bakat yang terpendam pada diri mereka. Mereka cenderung lebih senang melakukan hal-hal yang tidak bermanfaat, seperti mencoba meminum-minuman keras, karena di lingkungan Jorong Lawai banyak terdapat warung yang dijadikan tempat untuk melakukan perbuatan menyimpang tersebut sehingga sangat meresahkan masyarakat sekitar."

Berdasarkan data wawancara yang di dapat, diperoleh gambaran masih ada jorong yang belum efektif pelaksanaan program karang taruna dalam pembinaan remaja di Kenagarian Sitiung yang meliputi tentang : kurangnya pelaksanaan program karang taruna sebagai agen perubahan bagi remaja, kurang memfasilitasi kelompok, kurang membangkitkan kesadaran remaja, kurang menyampaikan informasi, Pelatihan, Pembinaan agama, Pembinaan kesejahteraan sosial, Pembinaan keterampilan dan Pembinaan masih kurang.

Rumusan masalah pada penelitian ini adalah bagaimana pelaksanaan program karang taruna dalam pembinaan remaja di Kenagarian Sitiung, apa faktor penghambat pelaksanaan program karang taruna di Kenagarian Sitiung serta bagaimana langkah efektif untuk menanggulangi permasalahan tersebut. Serta tujuan dari penulisan artikel ini adalah menciptakan sebuah karya ilmiah yang membahas secara detail bagaimana pelaksanaan program karang taruna dalam pembinaan remaja, hambatan pelaksanaan program karang taruna dalam membina remajanya dan langkah perbaikan pelaksanaan program karang taruna dalam pembinaan remaja. Sehingga penelitian ini bermanfaat untuk seluruh pengurus organisasi sebagai bekal untuk memperbaiki program karang taruna dalam membina remaja.

\section{METODE PENELITIAN}

Penelitian kualitatif jenis deskriptif ini mengkaji masalah yang sedang berlangsung dalam masyarakat. Dalam hal tersebut yaitu pelaksanaan program karang taruna dalam pembinaan remaja di Kenagarian Sitiung. Lokasi penelitian 
ini berada di Kenagarian Sitiung, Kecamatan Sitiung, Kabupaten Dharmasraya terutama pada Jorong Blok A Piruko Utara, Piruko Selatan, Sitiung, Pulai, Padang Sidondang dan Lawai. Pada penelitian ini informan penelitian adalah orang yang dipilih secara purposive sampling dimana informan secara sengaja ditentukan sesuai dengan kebutuhan penelitian. Adapun yang menjadi informan dalam penelitian ini adalah Kepala Jorong dan Ketua Pemuda. Sedangkan informan pendukung dalam penelitian ini terdiri dari masyarakat, tokoh agama dan tokoh adat. Jenis data dalam penelitian ini ada 2 jenis yaitu data primer yang merupakan hasil wawancara dengan para informan dan observasi terkait perilaku dan situasi pelaksanaan program karang taruna dalam pembinaan remaja yang dilakukan di kenagarian sitiung. Sedangkan data sekunder yakni data biografi karang taruna, program karang taruna, data terkait prestasi pemuda dan pemudi di Kenagarian Sitiung serta dokumen terkait lainnya.

Teknik analisis data pada penelitian ini pengumpulan data yang diperoleh dari berbagai sumber yaitu hasil dari observasi, wawancara yang dilakukan, dan studi dokumentasi yang didapatkan di lapangan melalui Kepala Jorong, ketua pemuda, tokoh adat dan masyarakat di Kenagarian Sitiung. Dengan kata lain reduksi data merupakan mencari fokus data yang telah ditemukan agar sesuai dengan permasalahan penelitian. ini dilakukan dengan uraian singkat atau narasi terkait dengan data pelaksanaan program karang taruna dalam pembinaan remaja, faktor penghambat pelaksanaan program karang taruna serta langkah perbaikan pelaksanaan program karang taruna dalam pembinaan remaja di Kenagarian Sitiung. Setelah melakukan beberapa tahap diatas seperti pengumpulan data, reduksi data dan penyajian data barulah data hasil penelitian dapat disimpulkan.

\section{HASIL DAN PEMBAHASAN}

Karang taruna merupakan organisasi sosial yang mempunyai visi dalam membangun remaja atau pemuda yang berkualitas, kreatif, beriman dan beramal sholeh serta mewujudkan nagari yang madani sehingga setiap organisasi karang taruna berusaha menjembatani seluruh aspek sosial di masyarakat. Menurut Mochamad Ridwan Arif (2014), Karang taruna yaitu suatu wadah pembinaan dan pengembangan generasi muda yang tumbuh atas kesadaran dan rasa tanggung jawab sosial yang bergerak dalam bidang kesejahteraan sosial secara fungsional yang dibina dan dikembangkan oleh Departemen Sosial. Hal ini sama dengan yang disampaikan oleh Sunoto (2017) bahwa karang taruna adalah organisasi sosial kemasyarakatan sebagai wadah dan sarana pengembangan setiap anggota masyarakat yang tumbuh dan berkembang atas dasar kesadaran dan tanggung jawab sosial dari, oleh dan untuk masyarakat terutama generasi muda di wilayah desa atau kelurahan atau komunitas adat sederajat terutama bergerak dibidang penyelenggaraan kesejahteraan sosial. Berbeda Elly Kumara (2013), bahwa karang taruna adalah organisasi kepemudaan di Indonesia sebagai wadah pengembangan generasi muda atau remaja nonpartisan yang tumbuh berdasarkan rasa kesdaran dan tanggung jawab oleh dan untuk 
masyarakat, khususnya generasi muda di desa atau di kelurahan yang anggotanya dimulai dari pemuda dan pemudi dari usia 11 hingga 45 tahun. Berikut program karang taruna di Kenagarian Sitiung:

Tabel 1: Program Karang Taruna di Kenagarian Sitiung

\begin{tabular}{|c|}
\hline $\begin{array}{c}\text { Program Karang Taruna di Kenagarian } \\
\text { Sitiung }\end{array}$ \\
\hline $\begin{array}{l}\text { Memberikan kemudahan bagi pengurus } \\
\text { dan anggota karang taruna untuk } \\
\text { mendapatkan pendidikan }\end{array}$ \\
\hline $\begin{array}{l}\text { Menyelenggarakan pelatihan keterampilan } \\
\text { menjahit dan tata busana }\end{array}$ \\
\hline $\begin{array}{l}\text { Menyelenggarakan } \\
\text { kewirausahaan }\end{array}$ \\
\hline Menyelenggarakan pelatihan pertanian \\
\hline $\begin{array}{l}\text { Melaksanakan gotong royong untuk } \\
\text { kebersihan lingkungan }\end{array}$ \\
\hline $\begin{array}{l}\text { Pembentukan koperasi pemuda karang } \\
\text { taruna }\end{array}$ \\
\hline $\begin{array}{l}\text { Membuka usaha pertanian, perkebunan, } \\
\text { perikanan dan peternakan }\end{array}$ \\
\hline $\begin{array}{l}\text { Pembentukan pengajian pemuda karang } \\
\text { taruna }\end{array}$ \\
\hline atan hari besar islam \\
\hline Iri besar nasional \\
\hline rakkan bulan suci Ramadhan \\
\hline $\begin{array}{l}\text { Pembentukkan grup olahraga seperti: sepak } \\
\text { bola, bola voli, sepak takraw }\end{array}$ \\
\hline $\begin{array}{l}\text { Mengadakan turnamen olahraga pada } \\
\text { harlah (hari lahir) karang taruna pada } \\
\text { tanggal } 20 \text { april setiap tahun }\end{array}$ \\
\hline Mengadakan turnamen olahraga HUT RI \\
\hline Mengaktifkan sanggar adat \\
\hline $\begin{array}{l}\text { Menjaga hubungan harmonis kar } \\
\text { dengan masyarakat. }\end{array}$ \\
\hline
\end{tabular}

Sumber: karang taruna Kenagarian Sitiung

Program-program tersebut dapat menunjang aktivitas remaja serta dapat membantu remaja untuk memiliki pengalaman baru dan kreatif dalam segala bidang. Dengan demikian dengan program yang bersifat sosial dapat membantu remaja dalam bersosialisasi di lingkungan masyarakat. Berikut merupakan program tahunan karang taruna Kenagarian Sitiung pada tahun 2018 yang menunjukkan bahwa ada beberapa program yang belum terealisasi kegiatannya karena dana dan anggota karang taruna yang tidak aktif dalam mengikuti kegiatankegiatan pada program karang taruna. berikut tabel program tahunan program karang taruna tahun 2018:

Tabel 2: Program Tahunan Karang Taruna Kenagarian Sitiung 2018

\begin{tabular}{|c|l|l|}
\hline No & \multicolumn{1}{|c|}{ Program tahunan } & Realisasi \\
\hline 1 & Kegiatan 17 agustusan & Berhasil \\
2 & Lomba pendidikan & \\
3 & Lomba permainan & Tidak berhasil \\
4 & Arisan anggota & Berhasil \\
5 & Rapat pengurus & Tidak berhasil \\
6 & Menjenguk warga yang & Berhasil \\
7 & sakit & Berhasil \\
8 & Membantu kegiatan & Beagamaan \\
9 & Pentas seni renungan & \\
\hline
\end{tabular}

Sumber: Karang Taruna Kenagarian Sitiung 2018

Sedangkan pelaksanaan program karang taruna dalam memperingati hari besar nasional seperti HUT 17 Agustus sering diperingati dan peran seorang remaja dalam program ini adalah mengikuti acara tersebut baik perlombaan antar jorong maupun antar kecamatan. Menurut data penelitian yang peneliti dapat alokasi dana jorong didapat dari iuran wajib dan iuran sukarela anggota. Menurut Setyo Manungga (2015) terdapat program karang taruna bahwa setiap pelaksanaan karang taruna diperlukan pendidikan serta pelatihan karang taruna. Seperti pelaksanaan program kegiatan pelatihan untuk para pengurus dan anggota warga karang taruna di Kenagarian Sitiung yaitu pelatihan kewirausahaan, pelatihan 
pertanian dan kerajinan. Dengan adanya pelatihan ini anggota hanya akan menambah skil mereka agar mereka mendapatkan pengetahuan dibidang kewirausahaan dan pertanian.

Dalam suatu kegiatan dalam pelaksanaan program karang taruna diperlukan suatu pembinaan khususnya di bidang kerohanian dan pembinaan mental. Maka dari itu di Kenagarian Sitiung dalam kegiatan karang taruna terdapat program karang taruna dibidang kerohanian dan pembinaan mental. Menurut Setyo Manungga (2015) bahwa pelaksanaan program karang taruna dalam pembinaan remaja diperlukan pengembangan kegiatan dan aktivitas karang taruna. Hal ini sama dengan program karang taruna di Kenagarian Sitiung dalam mengendalikan kegiatan tersebut maka seorang pengurus di bidang kerohanian dan pembinaan mental memiliki kewenangan dan tugas dalam membina remajanya. Sedangkan program karang taruna dibidang olahraga dan seni budaya yaitu melaksanakan selurug aktifitas olahraga dan seni budaya dalam rangka melalui kegiatan di bidang olahraga dan seni budaya baik secara temporer maupun rutin melalui club olahraga dan sanggar-sanggar seni budaya. Sedangkan dalam pelaksanaan program gotong royong untuk kebersihan lingkungan masih terlaksanaan sampai sekarang. Ada beberapa jorong yang setiap sebulan sekali atau pada saat akan memperingati hari besar nasional atau suatu acara dimana organisasi karang taruna akan melakukan kegiatan gotong royong. Jadi tidak semua jorong yang aktif dalam melaksanakan program karang taruna. banyak program yang hanya beberapa yang berjalan.

Demikianlah pelaksanaan program karang taruna di Kenagarian Sitiung bahwa ada beberapa program kegiatan yang terlaksana ada yang tidak terlaksana khususnya dalam pembinaan remajanya seperti wirid remaja hanya 2 jorong yang melaksanakan program tersebut. Namun program yang bertujuan untuk kemajuan jorongnya terlaksana seperti menyelenggarakan pelatihan untuk pemuda pemudinya, kegiatan gotong royong, memperingati hari besar dan lain-lain. Oleh sebab itu diperlukan pemograman kembali program karang taruna di Kenagarian Sitiung. Hal ini sama yang di sampaikan oleh penelitian yang dilakukan oleh Mochamad Ridwan Arif (2014) menyatakan bahwa perlunya peningkatan dalam pengetahuan untuk membina remaja agar sesuai dengan harapan yang diprogramkan sejak awal, sehingga diperlukan kerjasama yang baik antara pengurus, anggota dan perangkat dusun agar dapat menciptakan remaja yang berkualitas dan dapat diandalkan di lingkungan masyarakat terutama bangsa dan negara.

Dalam melaksanakan program karang taruna khususnya dalam pembina remaja tentu terdapat hambatan dalam mengopersikan program tersebut. Dalam kegiatan program karang taruna memang sulit dilaksanakan adalah pada remaja itu sendiri sebagai anggota karang taruna yang tidak memiliki jiwa sosialisasi dalam lingkungan masyarakat. Menurut Dewi Kurniasari (2013) ada faktor lain yang mempengaruhi pelaksanaan program karang taruna 
baik itu faktor internal ataupun eksternal sebagai berikut: Dari faktor internal yaitu meliputi hal mengatur waktu karena mayoritas warga karang taruna sudah bekerja dan mempunyai kesibukan masing-masing. Selain itu kecenderungan anggota karang taruna dalam mengikuti pola pikir anggota karang taruna yang lain sehingga organisasi tersebut kering akan ide. Hal lain yaitu ketidakberanian anggota karang taruna berbicara di depan umum. Sementara itu dari faktor eksternal yaitu kurangnya sokongan dana untuk mengefektifkan kegiatan dalam organisasi karang taruna tersebut, sehingga menjadikan program kerja kurang produktif. Hal ini berbeda dengan yang disampaikan oleh Setyo Manungga (2015) bahwa tujuan karang taruna yaitu terwujudnya kesejahteraan sosial yang memungkinkan pelaksanaan fungsi sosialnya sebagai manusia. Selain itu minimnya wawasan kebangsaan dan penerapan Pancasila akan membuat lunturnya semangat kebersamaan, gotong royong, kesetiakawanan, kepedulian dan kejujuran. Selain itu kendala karang taruna dalam membina remajanya yaitu kurangnya pengetahuan dan informasi yang dimiliki oleh remaja mengenai masalah-masalah yang dihadapi remaja seperti narkoba, perjudian, perkelahian, pencurian, ugal-ugalan dan lain sebagainya

Hal ini terbukti dari hasil penelitian yang peneliti lakukan masih minimnya pengetahuan pemuda Kenagarian Sitiung serta ketidak pedulian remaja untuk aktif dalam setiap kegiatan karang taruna. Kegiatan program karang taruna yang sering dilakukan di Kenagarian Sitiung lebih sering kerah keolahragaan karena di Kenagarian Sitiung sering melakukan even keolahragaan seperti sepak bola, bola voli dan lain sebagainya. Sedangkan dalam pembinaan remajanya dibidang kerohanian kurang. Karena dari peniliti lihat hanya beberapa Jorong yang melakukan kegiatan wirid remaja. Wirid remaja sangat penting untuk pembentukan mental remaja agar remaja terarah kearah positif dalam berpilaku di lingkungan masyarakat. Hambatan lain yang peneliti temukan adalah setiap kepengurusan kegiatan karang taruna di setiap Jorong di Kenagarian Sitiung berbeda prinsip. Dalam setiap program yang di rencanakan pengurus karang taruna ada beberapa Jorong yang terlaksana ada juga yang tidak terlaksana. Karena tidak terlaksanya kegiatan tersebut para pengurus karang taruna menghapus kegiatan tersebut.

Langkah efektif yang pertama didapat adalah mengulang kembali renacana program karang taruna sesuai dengan situasi dan kondisi remaja saat ini serta meningkatkan pelaksanaan program karang taruna di Kenagarian Sitiung. Dengan adanya rencana baru dan peningkatan program tentu akan ada perubahanperubahan yang sesuai dengan renacana yang telah disetel ulang. Dengan lebih memperbanyak kegiatan-kegiatan positif dan kerohanian agar mental remaja terbentuk. Langkah kedua setiap karang taruna berusaha membina remaja untuk memupuk bakat dan hobi yang dimiliki oleh terutama dalam bidang olahraga dan seni yakni dengan pelaksanaan kegiatan keolahragaan yaitu latihan sepak bola yang pernah diadakan pertandingan 
dengan organisasi pemuda karang taruna Jorong lain dan mengadakan sanggar seni untuk remaja karang taruna. Hal ini sama dengan Setyo Manungga (2015) bahwa peningkatan pendidikan dan pelatihan bagi pengurus maupun aktivis Karang Taruna dalam bidang manajemen organisasi, kepemimpinan dan kaderisasi, olahraga serta ketrampilan teknis. Dengan tujuan untuk memupuk rasa kebersamaan dan persaudaraan di antara para pemuda. Karang taruna di Kenagarian Sitiung juga memberikan bimbingan, motivasi dan pengarahan kepada semua anggotanya untuk kegiatan keagamaan misalnya kegiatan wirid remaja, ngaji bersama dan lain sebagainya. Langkah ketiga sering memberikan bermacam-macam semangat kepada remaja agar kedepannya karang taruna lebih maju. Selain itu dengan memberikan semangat kepada remaja akan meningkatkan kegiatan di karang taruna dan membuat remaja untuk sibuk kearah positif dan akan mengurangi angka kenakalan remaja atau membangun dan melatih diri mereka untuk lebih baik.

Dengan demikian diharapkan agar terjalinnya kerjasama yang baik antar pengurus karang taruna dan pemerintah kenagarian setempat serta para anggota karang taruna untuk bersama-sama dapat menanggulangi permasalahan pada remaja serta dapat membantu karang taruna dalam melaksanakan tugas dalam membina remaja. Sehingga terciptanya remaja yang berkualitas, mandiri dan bertanggung jawab di lingkungan masyarakat.

\section{KESIMPULAN}

$\begin{array}{cl}\text { Pada } & \text { dasarnya pelaksanaan } \\ \text { program karang taruna ini }\end{array}$ memberikan dampak yang positif bagi pengurus, remaja dan masyarakat sekitar di kenagarian sitiung. Selain itu program karang taruna juga berfungsi dalam membina remaja kearah positif dengan mendirikan program kegiatan yang menbawa remaja untuk bersosialisasi dan mengurangi angka kenakalan remaja. Walaupun dalam perlaksanaannya terdapat hambatan namun program ini tetap terus di lanjutkan serta meningkatkan monitoring dan evaluasi agar program karang taruna dapat dilaksanakan dengan baik. oleh sebab itu masih diperlukan peningkatan sesuai dengan program yang diharapkan, sehingga diperlukan kerjasama antara pengurus, anggota dan perangkat jorong agar dapat menciptakan remaja yang berkualitas dan dapat diandalkan dilingkungan masyarakat. Ada beberapa langkah perbaikan yang peneliti dapat dari beberapa narasumber yaitu:

a. Memprogramkan kembali program karang taruna di setiap Jorong di Kenagarian Sitiung dalam membina remaja.

b. Berusaha membina remaja untuk memupuk bakat dan hobi yang dimiliki terutama dalam bidang olahraga dan seni.

c. Memberikan bermacam-macam semangat kepada remaja agar kedepannya karang taruna lebih maju.

Berdasarkan kesimpulan di atas, maka penulis menyampaikan beberapa rekomendasi yang dianggap relevan dengan penelitian ini. Berdasarkan analisis pelaksanaan 
program karang taruna dalam pembinaan remaja ditemukan hambatan dan langkah efektif dalam menanggulangi hambatan tersebut, maka hal tersebut dapat digunakan untuk mengembangkan pemahaman pembaca yang di dalamnya memuat pelaksanaan program karang taruna dalam pembinaan remaja sebagaimana hasil penelitian ini.

\section{DAFTAR PUSTAKA}

Arief, M. R., \& Adi, A. S. (2014). Peran karang taruna dalam pembinaan remaja di dusun candi Desa Candinegoro Kecamatan Wonoayu Kabupaten Sidoarjo. Kajian Moral dan Kewarganegaraan, 1(2), 190-205.

Putri, E. K. T. (2015). Pengembangan Model Pemberdayaan Karang Taruna Terpadu Di Daerah Istimewa Yogyakarta. Pekerjaan Sosial, 12(1).

Kurniasari, D., Suyahmo, S., \& Lestari, P. (2016). Peranan Organisasi Karang Taruna Dalam Mengembangkan Kreativitas Generasi Muda di Desa Ngembalrejo. Unnes Civic Education Journal, 2(2).

Manungga, Setyo. 2015. Buku Profil Karang Taruna. Yogyakarta

Peraturan Menteri Sosial Republik Indonesia No. 77 Tahun 2010 Tentang Pedoman Dasar Karang Taruna. Diakses 30 september 2019. Pukul 17.55 wib.

Sarwono, Sarlito Wirawan. 2007. Psikologi Remaja. Jakarta : PT Rajagrafindo Persada.

Soekanto, Soerjono \& Budi, Sulistyowati. (2013). Sosiologi
Suatu Pengantar. Jakarta: Rajawali Pers

Sunoto, I., \& Nulhakim, A. L. (2017). Mengukur Tingkat Partisipasi Pemuda Dalam Program Karang Taruna dengan Pendekatan Metode Fuzzy Infrence System Mamdani. Simetris: Jurnal Teknik Mesin, Elektro dan Ilmu Komputer, 8(2), 711-720.

Undang-Undang Republik Indonesia No 4 Tahun 2009 pasal 22 ayat 1 tentang Kepemudaan. Diakses 21 februari 2019. Pukul 13.30 wib 